\title{
Studies on the Physical and Chemical Properties of Different Varieties of Rice Hulls Available in Sri Lanka
}

\author{
M.G.M.U. ISMAIL AND D.R.K. LOK ULIYANA \\ Minerals Technology Section, Ceylon Institute of Scientific and Industrial Research, \\ P.O. Box 787, Colombo 7, Sri Lanka
}

AND

R. P. GUNAWARDENA

Department of Chemistry, University of Peradeniya, Peradeniya, Sri Lanka.

(Date of receipt: 16 June 1982)

(Date of acceptance: 01 June 1983)

\begin{abstract}
Rice hull is a by-product in paddy milling and is largely a waste material. It has been found that rice hull can be used as a raw material in a number of industries. On developing the utilizations of rice hull, it is very essential to study physical and chemical properties of rice hull. In the present study physical properties and chemical properties of six different varieties of rice hull have been investigated.
\end{abstract}

External appearance, dimensions and weight per grain are very important to identify the different varieties of paddy grains. Calorific value of rice hull is $4127 \mathrm{cal} / \mathrm{g}$ and hence it can be used as a fuel. Specific gravity and bulk density of rice hull are 1.32 and $165.3 \mathrm{mg} / \mathrm{ml}$ respectively. Silica is the major inorganic constituent of rice hull and is $9.94 \%$ by weight. Moisture, organic matter, $\mathrm{K}_{2} \mathrm{O}, \mathrm{Na} \mathrm{a}_{2} \mathrm{O}, \mathrm{CaO} \mathrm{MgO}, \mathrm{Al}_{2} \mathrm{O}_{3}, \mathrm{Fe}_{2} \mathrm{O}_{3}, \mathrm{MnO}, \mathrm{P}_{2} \mathrm{O}_{5}, \mathrm{SO}_{3}$ and $\mathrm{Cl}$ of the different varieties of rice hull are $9.4 \%, 87.8 \%, 0.69 \%, 0.027 \%, 0.081 \%, 0.09 \%, 0.183 \%$, $0.014 \%, 0.034 \%, 0.24 \%, 0.082 \%$ and $0.007 \%$ respectively. A variation of these constituents among the different varieties of rice hull was observed, which is attributed to the factors such as soil condition, type of fertilizers used and climatic conditions etc. The presence of amorphous silica in rice hull was detected by scanning electron micrograph and differential thermal analysis. Therefore rice hull can be used for making pozzolanic type of cements. The amorphous silica in rice hull converts into a crystalline form at higher temperatures. This indicates that to get active rice hull, rice hull should be burnt under $700^{\circ} \mathrm{C}$.

\section{Introduction}

Rice hull, the outer covering of the rice grain is a by-product in paddy milling and forms 20 per cent by weight of the paddy milled. It is now largely a waste product. Only about 20 per cent of the available rice hulls are used as a fuel in some of the larger paddy mills.

Rice hulls are composed of 70 per cent organic matter, 20 per cent ash and 10 per cent moisture. At present research is in progress to make use of the ash obtained by burning rice hull under controlled conditions as a starting material for making cementitious binders by mixing with lime or portland cement. Rice hull ash consists 
essentially of silica and this should be in an amorphous form if cementitious properties are to be developed by the binder. For the development of these products details of the chemical and physical properties of the hull are essential.

In $1928 \mathrm{~J}_{\text {oachim }}{ }^{1}$ has analysed some of the varieties of rice hulls available in Sri Lanka. Subsequent to this no systematic work has been carried out to determine the physical and chemical properties of different varieties of rice hulls available in Sri Lanka. The present investigation was undertaken in order to make a systematic study of the physical and chemical properties of six different varieties of rice hulls available in Sri Lanka, namely BG 11-11, BG 94-1, BG 34-8, BG 90-2, BG 400-1 and BG 3-5.

\section{Experimental}

2.1 The specific gravity of the different varieties of rice hull were determined by evacuation method. ${ }^{2}$

2.2 The calorific values of the different varieties of rice hull were determined using an automatic adiabatic bomb calorimeter. Model of the instrument is autobomb CB-100.

2.3 The alkali oxides $\mathrm{K}_{2} \mathrm{O}, \mathrm{Na}_{2} \mathrm{O}$ contents, $\mathrm{CaO}, \mathrm{MgO}$ contents and $\mathrm{Al}_{2} \mathrm{O}_{3}, \mathrm{Fe}_{2} \mathrm{O}_{3}$, $\mathrm{MnO}_{2}{ }_{4} \mathrm{P}_{2} \mathrm{O}_{5}{ }^{4}$ contents were determined by Flame Photometer, Atomic Absorption Spectrophotometer and UV - Visible Spectrophotometer techniques respectively. Models of the instruments are Spectromom 381 L, Spectromom $190 \mathrm{~A}$ and Spectromiom 361 .

2.4 The $\mathrm{SO}_{3}$ content was determined by a gravimetric method $\left(\mathrm{SO}_{4}^{2-}\right.$ as $\left.\mathrm{BaSO}_{4}\right)$.

2.5 The chloride content was determined by a titrimetric method ${ }^{6}\left(\mathrm{Cl}^{-}\right.$as $\left.\mathrm{AgCl}\right)$.

2.6 The Scanning Electron Micrographs of the rice hull samples were studied using a JSM $25 \mathrm{~S}$ Scanning Electron Microscope.

2.7 The differential thermal analysis and thermogravimetric curves of two varieties of rice hull were obtained using a differential thermal analysis equipment. Model of the instrument is MOM, Q - Derivatograph.

\section{Results and Discussion}

\subsection{External Appearance, Dimensions and Weight per grain}

Six different varieties of paddy were used for this study and the results are given in Table I. It was found that the paddy grain of variety BG 11-11 is the smallest one and it can be clearly identified from the others. Grains of BG 94-1. BG 90-2 and BG 400-1 are almost same and difficult to identify from each other. Weight per grain of BG 90-2 is
the highest value. 


\subsection{Specific Gravity, Bulk Density and Calorific value of rice hulls}

The specific gravity, bulk density and calorific value of six different varieties of rice hull are tabulated in Table II. Variation of these properties among the different varieties of rice hull are $1.17-1.40,140.2-212.4 \mathrm{mg} / \mathrm{ml}$ and $4080.6-4199.9 \mathrm{cal} / \mathrm{g}$ respectively. The specific gravity and bulk density of BG $34-8$ variety is the lowest with 1.17 and $140.2 \mathrm{mg} / \mathrm{ml}$ respectively.

\subsection{Chemical Analysis of different varieties of Rice Hulls}

The chemical analysis of different varieties of rice hull indicates that the organic matter is the major constituent. Out of the varieties analysed the organic matter content of BG 11-11 was the lowest with 86.2 per cent, whereas BG $90-2$ contains the maximum amount about 91.4 per cent of organic matter.

The major inorganic component in rice hull is silica. The other constituent which were found in appreciable quantities are $\mathrm{K}_{2} \mathrm{O}, \mathrm{Na}_{2} \mathrm{O}, \mathrm{CaO}, \mathrm{MgO}, \mathrm{Al}_{2} \mathrm{O}_{3}, \mathrm{Fe}_{2} \mathrm{O}_{3}, \mathrm{MnO}, \mathrm{P}_{2} \mathrm{O}_{5}$, $\mathrm{SO}_{3}$ and $\mathrm{Cl}$. BG 11-11, BG 94-1 and $\mathrm{BG} 34-8$ which are mainly grown in the dry zone where the soil contains high alkali showed a high percentage of $\mathrm{K}_{2} \mathrm{O}$ and $\mathrm{Na}_{2} \mathrm{O}$.

BG 34-8 which is mainly grown in dry zones like Polonnaruwa, Anuradhapura and Kurunegala shows a higher percentage of $\mathrm{MnO}$. The variation of chemical constituents in these varieties of rice hull can be attributed to the soil conditon, climatic condition and type of fertilizers used.

Table 1.- External appearance, dimensions and weight per grain of different varieties of paddy grains.

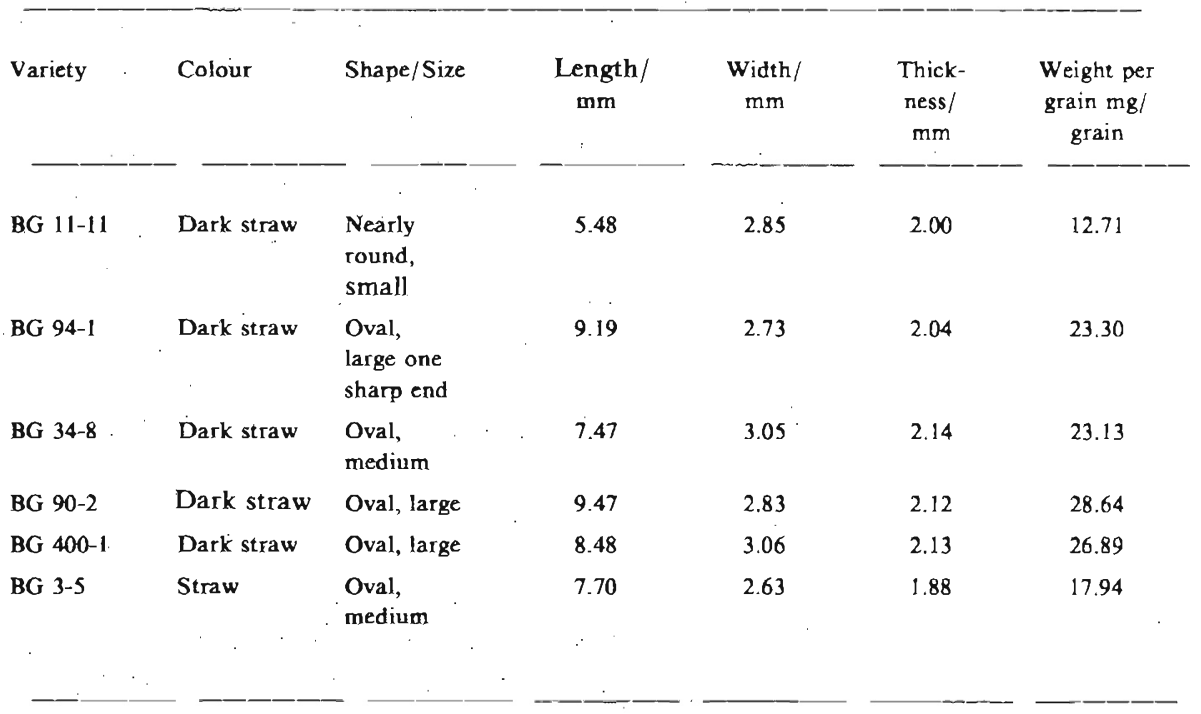


Table 2.- Specific gravity, bulk density and calorific value of different varieties of rice hulls.

$\begin{array}{lccc}\text { Variety } & \text { Specific gravity } & \text { Bulk density } \mathrm{mg} / \mathrm{ml} & \text { Calorific value cal/g } \\ \text { BG 11-11 } & 1.33 & 152.4 & 4080.6 \\ \text { BG 94-1 } & 1.36 & 212.4 & 4110.6 \\ \text { BG 34-8 } & 1.17 & 140.2 & 4144.6 \\ \text { BG 90-2 } & 1.33 & 175.7 & 4123.1 \\ \text { BG 400-1 } & 1.34 & 164.1 & 4199.9 \\ \text { BG 3-5 } & 1.40 & 146.9 & 4101.1 \\ - & - & -\end{array}$

Table 3. Chemical composition of different varieties of rice hull.

\begin{tabular}{|c|c|c|c|c|c|c|}
\hline Variety & BG 11-II & BG 94-1 & BG 34-8 & BG 90-2 & BG 400-1 & BG 3-5 \\
\hline $\mathrm{H}_{2} \mathrm{O}$ & 8.7079 & 8.8004 & 9.9438 & 9.4619 & 9.0888 & 10.5338 \\
\hline Organic & 86.2287 & 86.4432 & 87.1062 & 91.3466 & 90.1561 & 86.7337 \\
\hline $\mathrm{SiO}_{2}$ & 10.8515 & I 1.6061 & 10.3958 & 6.5866 & 8.7730 & 11.4362 \\
\hline $\mathrm{K}_{2} \mathrm{O}$ & 1.0080 & 0.7586 & 0.9638 & 0.5029 & 0.3023 & 0.5744 \\
\hline $\mathrm{Na}_{2} \mathrm{O}$ & 0.0347 & 0.0215 & 0.0186 & 0.0210 & 0.0181 & 0.0462 \\
\hline $\mathrm{CaO}$ & 0.0850 & 0.1020 & 0.0779 & 0.0653 & 0.0738 & 0.0805 \\
\hline $\mathrm{MgO}$ & 0.1174 & 0.0707 & 0.0910 & 0.1230 & 0.0652 & 0.0730 \\
\hline $\mathrm{Fe}_{2} \mathrm{O}_{3}$ & 0.0027 & 0.0188 & 0.0084 & 0.0321 & 0.0050 & 0.0177 \\
\hline $\mathrm{Al}_{2} \mathrm{O}_{3}$ & 0.2840 & 0.1502 & 0.2823 & 0.0758 & 0.2775 & 0.0254 \\
\hline $\mathrm{MnO}$ & 0.0161 & 0.0201 & 0.0729 & 0.0358 & 0.0346 & 0.0265 \\
\hline $\mathrm{P}_{2} \mathrm{O}_{5}$ & 0.2775 & 0.1917 & 0.2408 & 0.3758 & 0.1082 & 0.2180 \\
\hline $\mathrm{SO}_{3}$ & 0.2096 & - & 0.1363 & 0.0767 & - & 0.0690 \\
\hline $\mathrm{Cl}$ & 0.0016 & 0.0207 & 0.0104 & 0.0015 & - & 0.0103 \\
\hline Total & 99.1415 & 99.4036 & 99.4044 & 99.2431 & 99.8118 & 99.3119 \\
\hline
\end{tabular}

Chemical constituents - per cent by weight moisture free basis.

The chemical analysis of the six different varieties of rice hull studied are given in Table 3.

\subsection{Scanning Electron Microscope Studies}

A study of the electron micrographs show the cellular structure of the different varieties of rice hull and the presence and distribution patterns of amorphous silica in the cellular structure. The distribution pattern of amorphous silica varies from variety 
to variety and this is useful to characterize the different varieties of rice hull. Another significant feature of each variety of hull is the silica fibres arising from the surface of the cellular structure in different varieties. White areas of these photographs indicate the amorphous silica.

The scanning electron microphotographs of the different varieties of rice hull studied are given in Figure 1.

\subsection{Differential Thermal Analysis (DTA) and Differential Thermogravimetric (DTG) studies of different varieties of Rice Hull}

DTA curve of BG 11-11 shows a broad exothermic phase transformation of amorphous silica to crystalline silica and completes at $700^{\circ} \mathrm{C}(973 \mathrm{~K})$.

The DTA curve of BG 94-1 is also similar to BG 11-11 but the complete transformation of amorphous to crystalline-occurs at a higher temperature of $760^{\circ} \mathrm{C}$ $(1033 \mathrm{~K})$.

These results clearly indicate that the transformation of amorphous silica in rice hull to a crystalline form occurs with increase of temperature.

DGT curves of BG 11-11 and BG 94-1 show two significant peaks at $100^{\circ} \mathrm{C}(373 \mathrm{~K})$ and others at $250^{\circ} \mathrm{C}(523 \mathrm{~K})$ and $260^{\circ} \mathrm{C}(533 \mathrm{~K})$ respectively. The peak, at $100^{\circ} \mathrm{C}$ is due to the loss of moisture. The peaks at $250^{\circ} \mathrm{C}$ and $260^{\circ} \mathrm{C}$ are broad and indicate the loss of organic matter during a long range of temperature.

The DTA and DTG curves of the rice hull of the varieties BG 11-11 and BG 94-1 are given in Figure 2.

\section{Conclusion}

The present study clearly shows the variation of physical properties and chemical composition of the six different varieties of rice hull. 


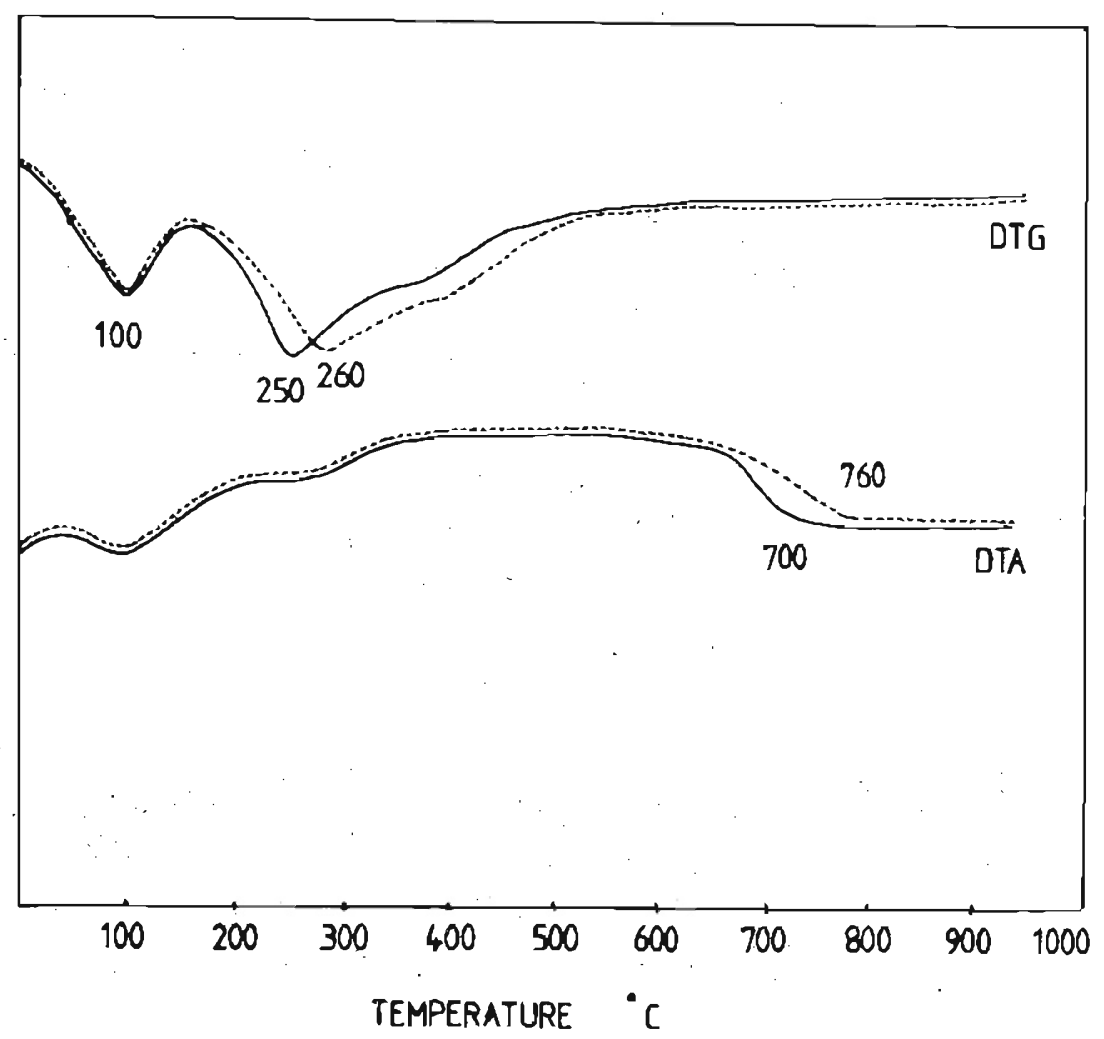

Figare 1. DTA and DTG curves of rice hull

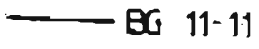

(2....... BG $94-1$ 

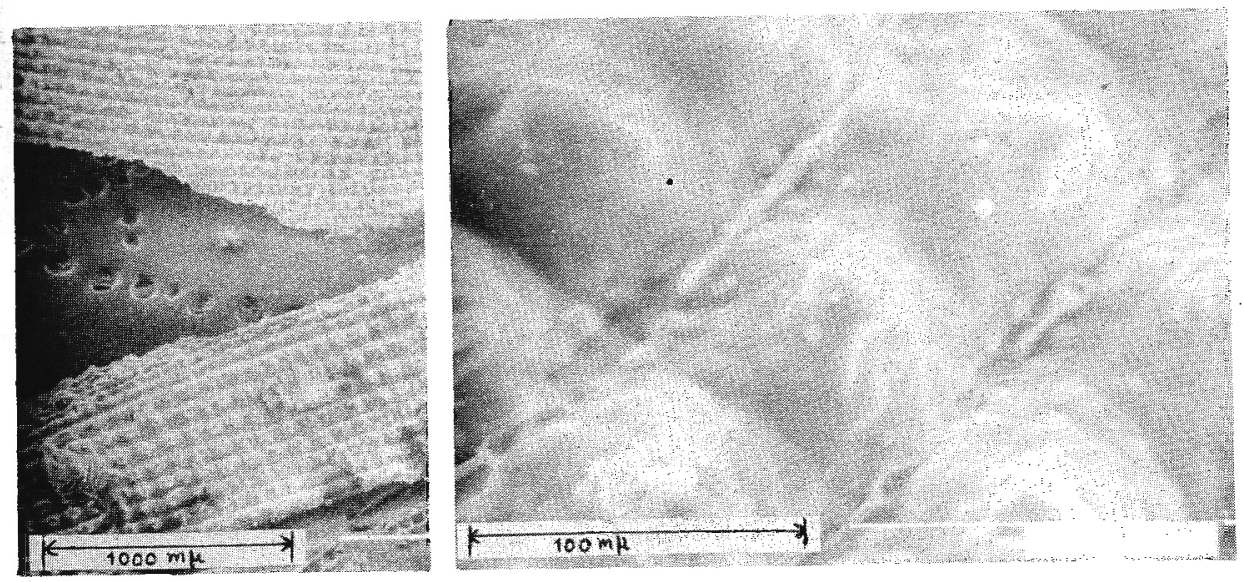

VARIETY BG 11-11
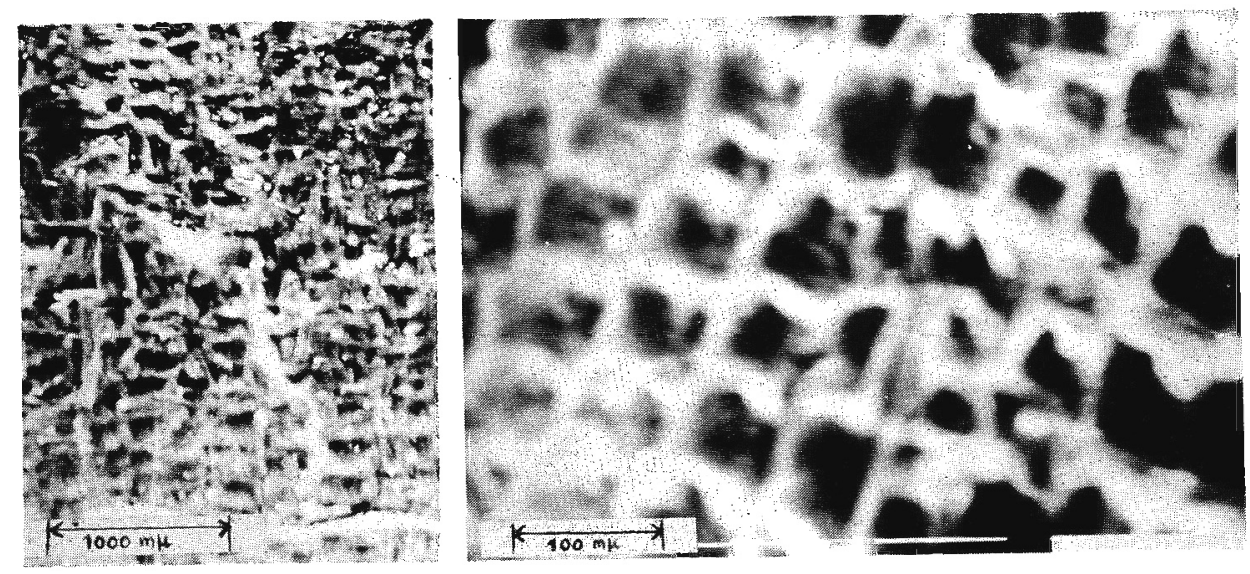

VARIETY BG 94-1

Figure 2. Scanning electron micro photographs of rice hull 

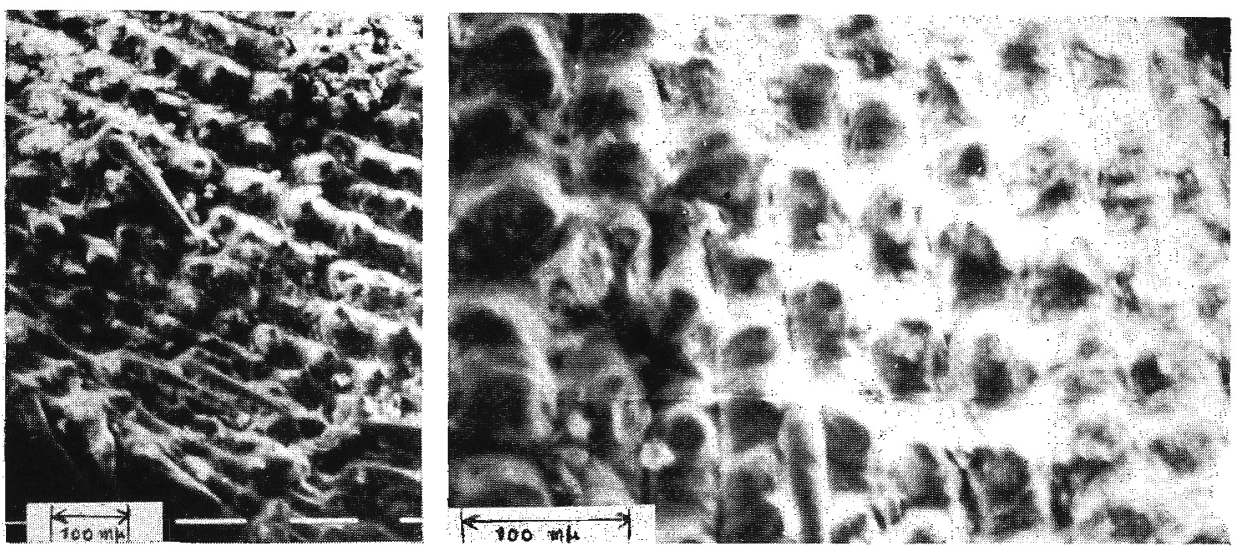

VARIETY BG 34-8
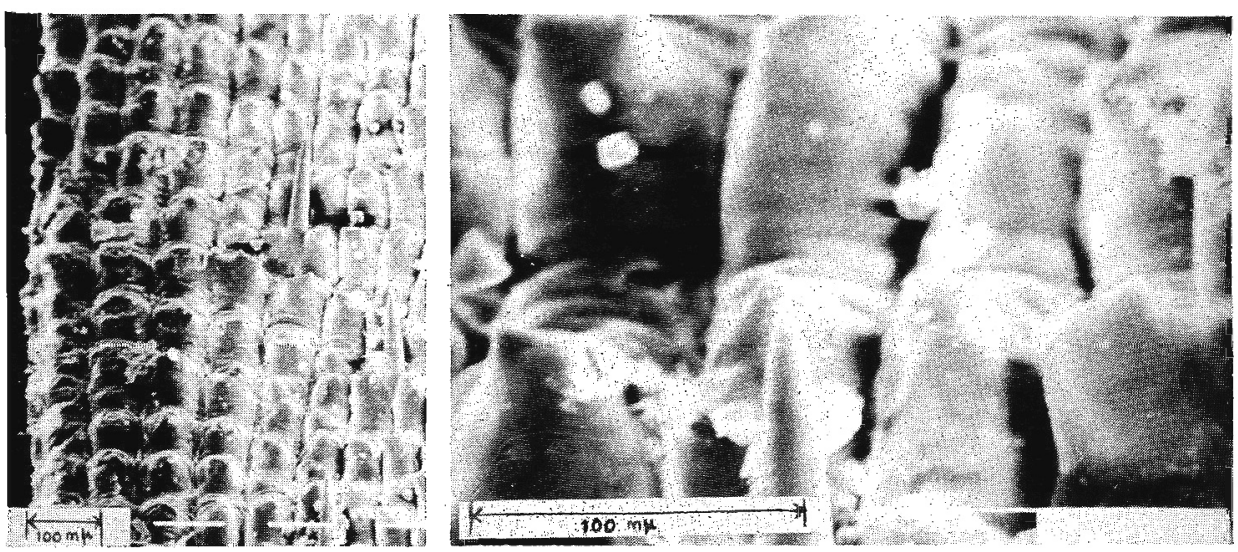

VARIETY BG 400-1

Figure 3. Scanning electron micro photographs of rice hull 

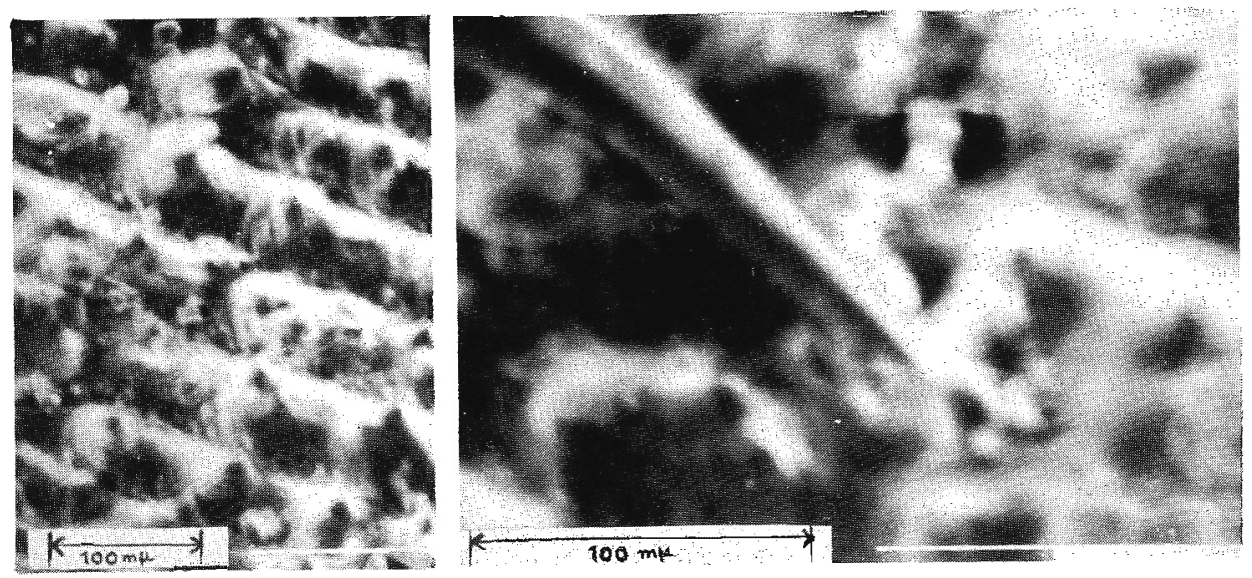

VARIETY BG 90-2
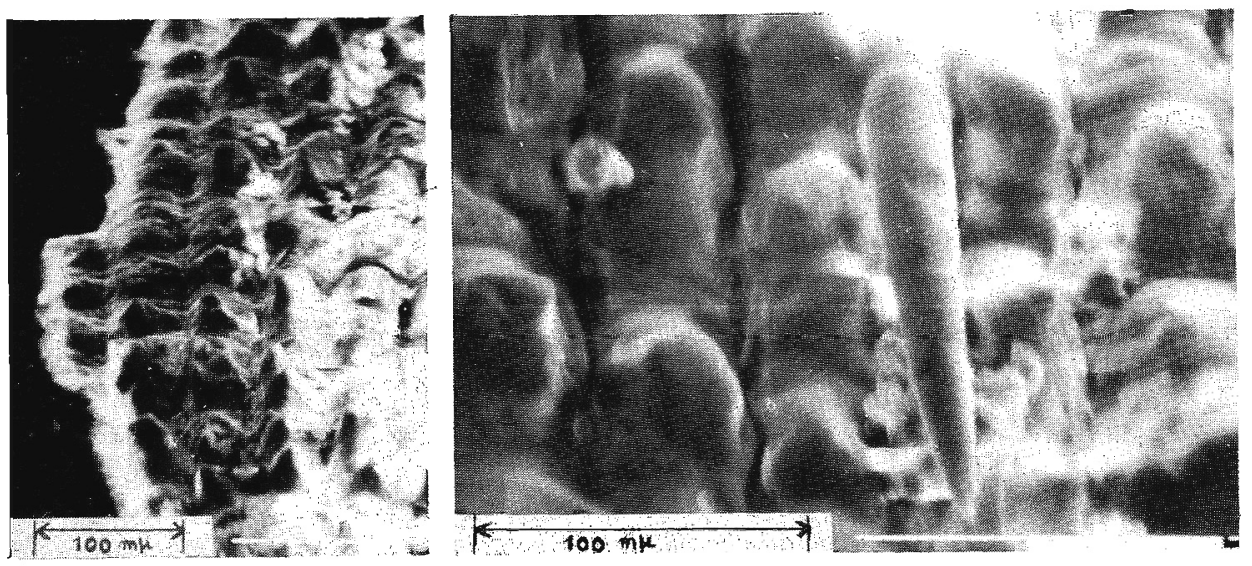

VARIETY BG 3-5

Figure 4. Scanning electron micro photographs of rice hull 


\subsection{External Appearance, Dimensions and Weight per grain}

These results are very important to identify the different varieties of paddy grains. The grains of BG 11-11, BG 34-8 and BG 3-5 can be clearly identified from the others. Average value of weight per grain is $22.1 \mathrm{mg} /$ grain.

\subsection{Specific Gravity, Bulk Density and Calorific Value}

The average calorific value of rice hull is $4127 \mathrm{cal} / \mathrm{g}$. The hull with high percentage of organic matter BG $400-1$ shows the highest calorific value of $4200 \mathrm{cal} / \mathrm{g}$.

The specific gravity and the bulk density of BG 34-8 variety is the lowest with 1.17 and $140.2 \mathrm{mg} / \mathrm{ml}$ respectively.

Average values of specific gravity and bulk density are 1.3211 and $165.3 \mathrm{mg} / \mathrm{ml}$ respectively.

Individual values show a slight variation from the average values.

\subsection{Chemical Composition of different varieties of Rice Hull}

Moisture content of the different varieties of rice hull varies from $8.7 \%$ to $10.5 \%$. The major constituent of rice hull is the organic matter and that varies from $86.2 \%$ to $91.4 \%$ among the varieties and has an average value of $88 \%$. Silica $\left(\mathrm{SiO}_{2}\right)$ is the major inorganic constituent of the rice hull and varies from $6.6 \%$ to $11.6 \%$. Average value of silica of the different varieties of rice hull is $9.94 \%$. Other inorganic constituents $\mathrm{K}_{2} \mathrm{O}$, $\mathrm{Na}_{2} \mathrm{O}, \mathrm{CaO}, \mathrm{MgO}, \mathrm{Al}_{2} \mathrm{O}_{3}, \mathrm{Fe}_{2} \mathrm{O}_{3}, \mathrm{MnO}, \mathrm{P}_{2} \mathrm{O}_{5}, \mathrm{SO}_{3}$ and $\mathrm{Cl}$ are also found in detectable amounts in the different varieties of rice hull. The variations of these constituents among the different varieties of rice hull are $0.3 \%-1 \%, 0.2 \%-0.05 \%, 0.07 \%-0.1 \%$, $0.07 \%-0.12 \%, 0.03-0.28 \%, 0.003 \%-0.03 \%, 0.02 \%-0.07 \%, 0.11 \%-0.38 \%, 0.07-0.21 \%$ and $0.002 \%-0.02 \%$ respectively. The average values of each constituent are $0.69 \%$, $0.027 \%, 0.081 \%, 0.09 \%, 0.183 \%, 0.014 \%, 0.034 \%, 0.24 \%, 0.082 \%$ and $0.007 \%$ respectively. These average values clearly indicate that there is a significant variation of the constituents $\mathrm{K}_{2} \mathrm{O}, \mathrm{Na}_{2} \mathrm{O}, \mathrm{Al}_{2} \mathrm{O}_{3}, \mathrm{Fe}_{2} \mathrm{O}_{3}, \mathrm{MnO}, \mathrm{P}_{2} \mathrm{O}_{3}, \mathrm{SO}_{3}$ and $\mathrm{Cl}$ of the different varieties of rice hull. Therefore it is important to know the variation of this kind of constituents in rice hull before studying the strength of cements obtained from the different varieties of rice hulls. The constituents $\mathrm{SO}_{3}$ and $\mathrm{Cl}$ are not found in all the varieties: The variation of these constituents in different varieties of rice hull mainly depends on factors like soil condition, climatic condition and type of fertilizers used etc. 


\subsection{Scanning Electron Microscope Studies}

The Scanning Electron Microscope studies indicated the presence of amorphous silica and that its distribution pattern could be utilised to distinguish the different varieties of rice hull. The distribution pattern of amorphous silica in each variety of hull is characteristic and could possibly be a genetical feature.

\section{Acknowledgements}

This work was supported by the Natural Resources. Energy and Science Authority of Sri Lanka. Grant No. RGB/81/43.

The authors wish to thank the staff of the Minerals Technology Section of The Ceylon Institute for Scientific and Industrial Research (CISIR) for their help in carrying out this work. The samples of rice hulls used in this study were supplied by the Agriculture Research Institute, Bathalagoda.

\section{References}

1. BEAGLE, E. C., (1978). FAO Agricultural Services Bulletin Rice-husk conversion to energy:. $\mathrm{p}-25$.

2. CHESTERS, J. H., (1973). Refractories and Properties, The Iron and Steel Institute, Carlton Hoise Terrace, London. p - 475.

3. DEVENPORT, W. H., (1949). Deterinination of Aluminium in presence of Iron, Analytical Chemistry, 2: N. $6, \mathrm{p}-710$.

4. Jeffer ry, ï. G., (1975). Chemical Methods of Rock Analysis, Pergamon Press, Oxford, p $-331,376$.

5. British standard 4550, part 2: (1970). British Standards Institution, Methods of Testing Cement, $\mathrm{p}-24$.

6. Standard Methods for the examination of water, sewage and industrial wastes, (1955) American Public Health Association, American Water Work Association, Federation of Sewage and Industrial Wastes Association, 10, p - 60. 